\title{
Article \\ Energy Communities: Technical, Legislative, Organizational, and Planning Features
}

\author{
Roberto De Lotto ${ }^{1}\left(\mathbb{D}\right.$, Calogero Micciché ${ }^{2}$, Elisabetta M. Venco ${ }^{1, *(\mathbb{D}}$, Angelo Bonaiti $^{2}\left(\mathbb{D}\right.$ and Riccardo De Napoli ${ }^{2}$ \\ 1 DICAr—Department of Civil Engineering and Architecture, University of Pavia, 27100 Pavia, Italy; \\ roberto.delotto@unipv.it \\ 2 Faculty of Law, Università Cattolica del Sacro Cuore, 20123 Milano, Italy; calogero.micciche@unicatt.it (C.M.); \\ angelo.bonaiti1@unicatt.it (A.B.); riccardo.denapoli@unicatt.it (R.D.N.) \\ * Correspondence: elisabettamaria.venco@unipv.it; Tel.: +39-038-298-5409
}

check for updates

Citation: De Lotto, R.; Micciché, C.; Venco, E.M.; Bonaiti, A.; De Napoli, R. Energy Communities: Technical, Legislative, Organizational, and Planning Features. Energies 2022, 15, 1731. https://doi.org/10.3390/ en15051731

Academic Editor: Ricardo J. Bessa

Received: 31 December 2021

Accepted: 23 February 2022

Published: 25 February 2022

Publisher's Note: MDPI stays neutral with regard to jurisdictional claims in published maps and institutional affiliations.

Copyright: (c) 2022 by the authors. Licensee MDPI, Basel, Switzerland. This article is an open access article distributed under the terms and conditions of the Creative Commons Attribution (CC BY) license (https:// creativecommons.org/licenses/by/ $4.0 /)$.

\begin{abstract}
Worldwide, the use of fossil fuels covers almost $80 \%$ of the entire energy needs. In the European Union (EU), 2020 represents a watershed: for the first time, renewables were the main source of electricity. In Italy, the latest surveys demonstrate an increase in the use of alternative energy sources. European legislative framework highlights the importance of these new trends encouraging (and imposing) the use of renewables. The necessity to become more proactive in the energy production-consumption process and in the achievement of sustainability targets brings people to create Energy Communities (ECs) to manage their own energy supply chain. The authors present an overview of the main legislative framework in the EU and Italy in relation to ECs, analyzing the energy consumption, the electricity and heat energy production potentiality, and the energy balance in a portion of an Italian middle-size city in the Milan metropolitan area. Moreover, they underline the technical, regulatory, and planning possibilities to achieve energy independence, exchanging energy among the selected urban district when there is a surplus in production. Lastly, the authors underline the strengths and barriers to the development of ECs.
\end{abstract}

Keywords: energy community; energy island; renewable energy; urban planning; legislative framework; urban policies

\section{Introduction}

At the present time, many of the most relevant environmental and social challenges associated with urban development are linked to un-proportionally high energy consumption, to greenhouse gas emissions, to vast ecological footprint, to excessive resource consumption (land, fossil fuels, water, food), and to infrastructure costs aggravated by urban sprawl, slums growth, and lack of livelihood opportunities. According to the last forecasts of the International Energy Agency (IEA) [1], electricity energy demand is projected to approach 42.000 TWh by 2050, almost $80 \%$ more than today's level. In one day, over 350 TWh are consumed, and over $80 \%$ is not from renewable sources [2].

Electricity is crucial for our lifestyles: from residential and domestic uses, to leisure, and to industrial purposes. With demographic expansion, economic growth, development of transportation systems, and urban sprawl, the demand for electricity has been growing as well [3-5]. According to a prevision made in 2019 by the IEA, the global electricity demand will grow at $2.1 \%$ per year to 2040 with a demand increase of 13,000 terawatt-hours (TWh) in 2040 compared to today [6]. Moreover, after a strong reduction in 2020, the electricity demand is expected to increase again in 2021, pushing consumption to higher levels than pre-pandemic levels [1]. Finally, many scholars consider cities as the biggest consumers of electricity [7].

In this many-sided scenario, 2020 marks an important achievement: for the first time, renewables overtook fossil fuels as the EU's main power source (38\% of EU electricity, fossil fuels $37 \%$ and nuclear $25 \%$ ). Moreover, the share of renewable energy sources in the 
overall EU energy mix reached at least 22\%, although some Member States are far from their national binding target. Italy ranks among the best countries for the performance in terms of the exploitation of renewable energy: it has reached the European targets for 2020 in advance, starting from 2014: in the electricity sector, 37\% of Italian consumption in 2020 was satisfied by renewable sources (solar, photovoltaic, hydraulic, geothermal, bioenergy) [8].

The current EU "Clean Energy Package" fits into the recent international effort on climate and sustainable living (among all the fundamental steps: from the United Nations Framework Convention on Climate Change-UNFCCC in 1992; Kyoto Protocol in 1997; to Agenda 2030, Sustainable Development Goals, and Paris Agreement in 2015 till XXV Conference of the Parties-COP26 in 2021). It aims to place local consumers at the heart of the energy transition, and the achievement of the Energy Union requires a fundamental transformation of Europe's energy system [9]. The adoption of the European Climate Law and the EU Commission communication COM(2021)550 of the "Fit for 55\%" package, which contains legislative proposals to revise the EU 2030 climate and energy framework (setting even higher targets than those provided in the European Green Deal), marked two major steps towards the definition of a credible framework to ensure the above. Member States' Recovery and Resilience Plans provide a boost to climate-related investments by at least EUR 177 billion and foster necessary reforms to support the climate and energy transition [10].

Considering local energy systems with weak or non-existing grid connections, implies giving citizens (as energy consumers and producers) the power to manage a renewablebased energy infrastructure to the local people, energy consumers, and producers.

By seizing the opportunities offered by new technologies, citizens and common people, in general, are already gaining relevance in the energy sector through direct, inclusive, and participatory actions. It is estimated that 264 million European citizens will join the energy market as prosumers, generating up to $45 \%$ of the system's renewable electricity.

The term prosumer refers to users that are not just passive consumers but are active actors in the various stages of the production process as producers: they are active players in the management of energy flows, reaching a relative energy autonomy and economic benefits [11,12]. This implies that prosumers can generate electricity just to meet their own needs (off-grid prosumption) and/or generated surpluses for other users feeding energy into the network (on-grid prosumption) $[13,14]$. Moreover, it is important to clarify the term prosumption as the ability to produce a part of what one consumes in a sustainable manner. Usually, it refers to the informal production of goods and services at the home or community level, but it can also be widened to the city level [7].

In Europe, the first energy cooperatives were founded at the end of the 19th century to support the electrification of settlements in rural areas. It was mainly due to a lack of national grids and greater strategic importance given to urban areas by stakeholders. More recently, the progressive liberalization of energy markets and the development of technologies towards decentralized energy systems allowed Energy Communities to establish themselves as new actors with a prominent role in the energy market $[15,16]$.

In this trend, the recast renewable energy directive (EU) No. 2018/2001 [17] and the recast electricity market directive (EU) No. 2019/944 [18] introduced a regulatory framework for the promotion of consumer co-ownership in (renewable) energy production. Following these new rules concerning collective self-consumption, Citizen Energy Communities (CEC) and Renewable Energy Communities (REC) are expected to attract private financial means, lower public resistance to decentralized (renewable) energy projects, and incentivize consumer participation. These communities have a primary objective of providing environmental, economic, and social community benefits and can help to increase the share of renewables in local areas with limited impact on the public grid and the energy efficiency of the local energy systems as bottom-up actions. The local approach helps to engage the local citizens to become active contributors to a clean energy society and to influence other consumers to adopt similar behavior. 
In the Italian legal system, the reality of Energy Communities (EC) has attracted the attention of the national legislator on the impulse of European Union law, guided by the international climate agreements. The mentioned EU Directives have been recently transposed with Legislative Decrees of 8 November 2021 No. 199 and No. 210, which will fully enter into force following the adoption of the implementing regulatory acts [19-21].

\section{Logical Framework: Aim and Method}

The authors propose research that aims at defining a management framework to secure and maximize the level of energy autarky [22] (grid independence and direct profit for the producers and consumers-prosumers), optimizing the process of energy production and consumption at local levels. Moreover, we do not refer only to isolated Energy Communities but to more complex structures, such as the Urban Energy Islands. They are supposed to be urbanized systems with appropriate technological infrastructures combined to become a single body that produces and consumes energy from renewable sources in spatially close environments [23].

Therefore, the study of energy consumption and of electricity and heat energy production potentiality are applied to the context of Segrate (a middle-size city in the East side of the Metropolitan Area of Milan, Italy), and the energy balance is defined in the presence and absence of renewable energy sources use. Consequently, in order to achieve energy independence, the possibility (from technical, regulatory, and planning points of view) of exchanging energy among the urban district areas is studied.

The paper is structured, after an introduction part, in four main sections. First, the European and Italian legislative framework that regulates the activities in the field of EC is presented, and the definitions and characteristics of the existing types of EC are also provided. The next two sections focus on the study, analysis, and evaluation of the Segrate case study, which, at the present time, has not yet been physically developed and for which some simplifications have been made during the calculation of the energy needs of each urban function. Finally, an extensive discussion is proposed highlighting the peculiarities of ECs (emerged from the case study application) and the existing barriers to their development. Moreover, some explanations are also provided on the regulatory aspects at the municipal-administrative level, which will have to be carefully analyzed and adapted to the needs imposed by ECs development.

\section{Materials}

\subsection{EU Legislative Framework on Environmental/Energy Sustainability}

With Directive No. 2001/77/CE [24], the European Community committed to improving the production of electricity from renewable energy sources, providing for a preliminary set of rules that expressly served as a base for a future community legal framework. Directive No. 2001/77 fostered the development of the internal electricity market through the harmonization of incentive mechanisms or other support schemes (e.g., simplification of plant authorization process). Pursuant to the energy purposes expressed into the UN Kyoto Protocol, the Directive required Member States to specify national indicative targets for the consumption of electricity produced from renewable sources, which should have reached the $12 \%$ of gross national energy consumption by 2010 (22.1\% share of electricity). On the same path, Directive No. 2003/30/CE aimed at promoting the use of renewable fuels within the transport field [25] and imposed that at least $5.75 \%$ of petrol and diesel consumption should be replaced with renewable fuels, in any form.

The first wide regulatory intervention by the European Union in relation to renewable energy is Directive No. 2009/28/EC (so-called RED I Directive) [26], which systematically revisited the regulations on the promotion of energy from renewable sources use. It raised the targets set forth in Directive 2001/77 to ensure at least a 20\% share of energy from renewable sources in the community's gross final consumption of energy in 2020. Aside from simplifying the administrative procedure of authorization or license, energy efficiency and energy saving should be pursued by the Member States through the promotion and 
support of technological development. Such a process embraced the electricity market, heating and cooling systems (for both industrial and residential areas), as well as fuels in the transport sector.

Subsequently, in October 2014, the EU adopted the "Framework for energy and climate 2030 ", a programmatic document that set the strategic goals and objectives to be achieved in 2020-2030 on the reduction of greenhouse gases and the development of infrastructures for the energy market. Hence, the EU Commission has published the Energy Union Strategy (COM/2015/080), which identified the five dimensions on which the Union's sustainable energy policy should be developed: security and diversification of energy sources; market integration; energy efficiency; decarbonization of economic-productive processes; research, innovation, and competitiveness.

Between the end of 2018 and the first half of 2019, the programmatic objectives identified in the Strategy have been legally implemented with the adoption of the Clean Energy Package (CEP), composed of several legislative acts (EU Directives and Regulations). It has imposed a reduction in net greenhouse gas emissions-by 2030 - equal to $40 \%$ of the values recorded in 1990 and has outlined the contents of energy governance in the Union in order to coordinate-from an organizational point of view-the development of the five dimensions and requires the Member States to adopt specific integrated plans on climate and energy to promote integration between energy policies and environmental sustainability.

With Directive No. 2018/2001, the so-called RED II Directive [17], concerning the promotion of renewable energies, the EU defines that self-consumption in community form is a tool for enhancing the production of energy from non-polluting sources, which by 2030 must amount to the $32 \%$ of the total energy consumed (at least $14 \%$ in the transport sector). If effectively implemented and transposed into national law, the RED II Directive has the potential to accelerate a more sustainable energy transition by facilitating the widespread implementation of Renewable Energy Communities (RECs). The European Commission explicitly emphasized the role of prosumers and thus advocated reducing energy costs through self-generation and consumption and expanding the consumer's role through intermediation and collective participation schemes [27].

Moreover, with Directive n. 2019/944 [18], which redefined the boundaries and functioning of the EU electricity market, the access and operation of such a legal entity within the electricity market are guaranteed.

Finally, the following should be noted: the communication from the EU Commission $\operatorname{COM}(2019) 640$, which described the so-called European Green Deal with the aim of eliminating net greenhouse gas emissions by 2050; Regulation EU/2021/1119, which imposed both the internal reduction of net greenhouse gas emissions by at least $55 \%$ compared to 1990 levels by 2030 and the total elimination of net emissions by 2050; the final communication of the EU Commission COM(2021)550 ("Fit for 55\%" package), which proposes to revise the minimum thresholds of energy produced from non-fossil energy sources by raising the target of renewables in the EU energy mix from the current $32 \%$ to $40 \%$.

\subsection{Italian Regulatory Framework on Environmental and Energy Sustainability}

The intense legislative activity of the EU in recent years has triggered an internal national process of integration and amendment of the in-force regulation.

The Directive n. 2009/28 (RED I) was originally incorporated into the internal system with Legislative Decree 28/2011, which governed the authorization procedures for the construction and operation of energy plants powered by renewable sources without considering Energy Communities.

Regulation n. 2018/1999 imposed on each Member State the adoption of a National Energy and Climate Plan in order to specify, in detail, the strategic objectives and actions taken by individual countries to promote the green transition in the energy sector. In 2019, Italy presented the Integrated National Plan for Energy and Climate (Piano Nazionale Integrato per l'Energia e il Clima-PNIEC). It presents the topic of Energy Communities regulating them under two profiles: the first relating to the production of electricity from renewable 
sources with a view of decarbonizing the production system; the second concerning the integration of the electricity market [28].

The 2021 Italian National Recovery and Resilience Plan (Piano Nazione di Ripresa e Resilienza-PNRR) deals with the matter of renewables by allocating and specifying the financial resources reserved for the energy transition. As part of Mission 2 (green revolution and ecological transition), Component 2 is dedicated to "Renewable energy, hydrogen, and sustainable mobility", and allocates 2.2 billion Euros in investments for the promotion of renewable energies through support for Energy Communities and collective self-production structures. The recipients of this investment, as members of these communities or as part of a collective self-consumption group, are local public administrations, families, and micro-enterprises. The importance of the role attributed to the climate issue in the PNRR is highlighted by the obligation to allocate at least $37 \%$ of the total resources to the ecological transition [29].

\subsection{Energy Communities}

Energy Communities are significant elements in the energy transition towards a lowcarbon Europe and reflect an expanding desire to find alternative ways of organizing and governing energy systems [21,30-35]. It is a new form of social movement in which citizens voluntarily participate in renewable energy projects and/or in energy efficiency projects allowing more inclusive and democratic processes. The production of energy from renewable sources and the scattering of the system "production and consumption" are different concepts that can be overlapped (for example, in the renewable islands concept) or that can work in parallel. In this sense, considering the geographical distribution as a basic element, the related, spatially distributed social groups are the main actors of the community [36]. It should be noted that the above distinction is not to be considered as an assessment of a system's strengths or weaknesses but as a description of their coexistence and/or complementarity: the sharing of energy production and distribution does not depend strictly on renewable sources. By 2050, nearly half of all European homes could be involved in renewable energy production, and an important section could come through collective participation within ECs.

Generally speaking, an Energy Community initiative, as an energy producer, is a common sharing of responsibilities and benefits: enhancing local value helping to implement local, sustainable projects in order to achieve energy independence, reduce carbon emissions and fuel consumption, as well as contribute to the local prosperity; generating financial returns for the community; creating local jobs and establishing a competitive field for investors; education and mobilization of citizens alongside municipalities and local authorities; social cohesion.

Energy Communities can perform both traditional activities (generation, supply, consumption, distribution) and engage in new business models. An increasing number of ECs provide additional services, such as: electro-mobility; energy efficiency and savings (i.e., buildings renewal, energy checking, consumption monitoring, heating, and air quality assessments); flexibility of uses, energy storage and smart grid integration; energy monitoring and grid management; financial services; consultation services to develop community initiatives [19,35,37-40].

Through the CEP, the EU has introduced the concept of Energy Communities in its legislation: Citizen Energy Communities (CEC) and Renewable Energy Communities (REC).

More specifically, Article 2 of Directive RED II defines the REC as a legal entity selfproducing, self-consuming, sharing, and selling energy from renewable sources, pursuing environmental, economic, or social community benefits. Member States should, therefore, ensure that they can participate in available support schemes as the large participants. Article 2 of Directive No. 2019/944 defines the CEC as a legal entity with the same purposes as REC's one, including new rules that enable active consumer participation, individually or through CEC, in all markets, either by generating, consuming, sharing, or selling electricity or by providing diverse services through demand-response and storage. 
The Directive aims to improve the uptake of Energy Communities. Moreover, it makes it easier for citizens to efficiently integrate into the electricity system as active participants.

Despite the similarity of the two definitions, RECs and CECs have significant differences: CECs may produce energy even from non-renewable sources; RECs are subject to a proximity principle which limits the territorial extension of the community; a medium enterprise must not join a CEC, while it is eligible as a REC member (big undertakings are excluded from both); the participation in a REC must not be the primary commercial or professional activity of a private enterprise, while it appears to be allowed for the CEC.

Following the adoption of Directive No. 2018/2001, the Italian legislator has provided for a transitory legal regime of the RECs, which mainly reproduces the content of the EU legislation. More specifically, Article 42-bis of Law Decree No. 16/2019 has allowed the Energy Communities to self-produce and self-consume electric energy (apparently not heat energy) from renewable sources, limiting the total plant power to $200 \mathrm{~kW}$ and provided for incentives in favor of the communities granted by the Manager of the Energy Services (Gestore dei Servizi Energetici-GSE) based on the quantity of energy produced and shared with the electric energy system. The plant power limitation and the administrative weight of the procedure before the GSE render the effective promotion of the RECs more difficult.

Meanwhile, the Italian Government and Parliament implemented Directive No. 2018/2001 [17] and Directive No. 2019/944 [18] through Legislative Decrees of 8 November 2021 No. 199 and No. 210 [41], which inter alia regulate the creation and execution of the Energy Communities (respectively, RECs and CECs). More specifically, Article 31 of Decree No. 199 and Article 14 of Decree No. 210, respectively, transposed the EU definition of REC and CEC, distinguishing them from the individual or aggregate auto production and consumption of energy. The latter case does not imply the creation of a new entity, which is instead a premise of an Energy Community. Moreover, Article 31 of Decree No. 199 refers to Article 14 of Decree No. 210 as to the energy distribution and storage methods.

Despite delivering certainty on the composition and purposes of Energy Communities, the mentioned provisions present the following obstacles or criticalities that may be seen as regulatory or administrative burdens:

- The general provisions regarding RECs seem to be restricted to electricity only; this conclusion is confirmed considering that the energy distribution within RECs must be carried out according to the provisions regarding CECs, which are referred to the electricity market only. Thus, the community model may not be directly applicable to renewable thermic energy as well;

- The plant power for RECs has been limited to $1 \mathrm{MW}$. Although the threshold is higher than the one set before (Article 42-bis set a $200-\mathrm{kW}$ limit), such restriction will undermine the energetic capacity of the communities and the extension of the community (which is already restricted by the proximity principles);

- The exclusion of big enterprises-deriving from the EU Directives and adopted by the national legislator-may negatively affect the promotion of the community model;

- The energy distribution may be primarily carried out by CECs through existing facilities, while the realization of new distribution networks is allowed for "specific technical reasons" only; such provision indirectly applies to the RECs as well, given the reference made by Article 31 of Decree No. 199 to Article 14 of Decree No. 210. In any case, the Communities are entitled to realize storage systems;

- The effective execution of the Energy Communities system requires the adoption of the implementation rules by ARERA, which may take at least 6 months (see Par. 10, Article 14 of Decree No. 210) [42].

The attention to such issues has already been drawn by operators and associations during the parliamentary process of review of such Decrees [43]. However, the opinions rendered by the Senate of the Republic and the Chamber of the Deputes did not report them to the Government. As such, the in-force Decrees did not take them into account. 


\subsection{ECs across EU}

In all of Europe, there are about 3500 renewable energy cooperatives, considered as a type of Energy Community [44]. The total amount increases when including cooperatives, eco-villages, small-scale heating organizations, and other projects led by citizen groups. Moreover, the geographical spread, the size from the local to regional to nation-wide levels, and the number of members (from a few to thousands) are quite heterogeneous. Energy projects exist in diverse forms across Europe, providing different services and activities (generation, supply, consumption and energy sharing, distribution and networks, electromobility, financial services) and using different Energy technologies (wind, solar, hydro, bioenergy, geothermal) [45].

ECs are very heterogeneous in terms of organizational models and legal forms: energy cooperative is the most common type. It is possible to also find an association, partnership, development trust, and private companies or entities with public participation [29].

In a general overview of Europe, Denmark appears as a pioneer country in the development of energy cooperatives since the 1970s; Germany began to support and encourage the diffusion of energy cooperatives in the aftermath of the Fukushima disaster in 2011; from the 1990s, Great Britain and the Netherlands promoted renewable energy installations through national incentives and grants, allowing small producers and communities to receive economic support for electricity production from renewable sources [44,45].

In Italy, there are already many communities and energy cooperatives located mainly in the northern regions. Some of them have been active since the first decades of the 20th century as the Cooperative FUNES, which was born in 1921 in Alto Adige with the name of "Società Elettrica Santa Maddalena". Here, the electricity for local uses is produced by three hydroelectric plants (San Pietro 775 kW, Meles 2698 kW, and Santa Maddalena 225 kW), a photovoltaic system $(170 \mathrm{~kW})$, and two biomass district heating systems $(1100 \mathrm{~kW}$ and $700 \mathrm{~kW}$ ). The surplus (all 100\% renewable) is put into the national grid, and the revenues are reinvested in the same area for further technological developments and for social aid to the residents [11].

Furthermore, according to Legambiente research, there are 40 examples of $100 \%$ Renewable Municipalities: here, renewable sources can satisfy the electricity and heat consumption of resident families [46]. In particular, biomass and geothermal plants connected to district heating networks fully satisfy the thermal needs of resident citizens, and mini hydroelectric and solar photovoltaic systems satisfy the electrical needs. The entire supply chain is managed by energy cooperatives or public companies, in which citizens, public administrations, and local companies are united with a general goal of self-production and energy independence. There are also 3493 municipalities already 100\% electric; that is, able to produce, thanks to one or more technologies, more electricity than is needed by the resident families [46]. The quick response of Italy to the RED-II Directive has led to a flourishing of RECs, but the national situation is not homogeneous. In the modern forms, the first Italian region encouraging RECs with Regional Law were Piemonte in 2018, followed by Apulia in 2019 and Liguria in 2020. Legambiente issued the report "Comunità Rinnovabili 2021" where 46 projects on Italian RECs are listed. Among them, there are 15 single self-consumption projects, 4 collective self-consumption projects, and 27 REC projects [46-49].

\section{Segrate Case Study: Urban and Energy Analysis}

Segrate is a municipality on the east side of Milan metropolitan area. It is $17.49 \mathrm{~km}^{2}$. wide, it has almost 36,000 inhabitants, and a population density of 2000 inhabitants per $\mathrm{km}^{2}$. As it happened in many municipalities in the close ring of Milan, Segrate's development started from the 1960s from a rural origin. It is essentially a residential settlement with some tertiary excellences: Mondadori (designed by Niemeyer), Fininvest, IBM, and Microsoft (now moved). The contemporary city, derived from the aggregation of separate neighborhoods, some of which have a very high quality of urban fabric and architecture. It is important to highlight the presence of wide-scale infrastructures: Forlanini Airport (Linate), 
three multimodal logistic centers, high-speed train lines, and main roads that connect the east of Lombardy to Milan. The environmental impact of such big infrastructures is extremely relevant, considering both the occupation of soil and the impact of activities and induced traffic [50].

Segrate is composed of eight recognizable neighborhoods (Segrate Centro, Rovagnasco, Milano Due, Redecesio, Lavanderie, Villaggio Ambrosiano, Novegro, and San Felice) that were built with an independent system of mobility and energy supply with an isotropic distribution of high-level public services equipment. For the presented research, three specific neighborhoods are considered: Segrate Centro, Villaggio Ambrosiano, and Rovagnasco (Figure 1).

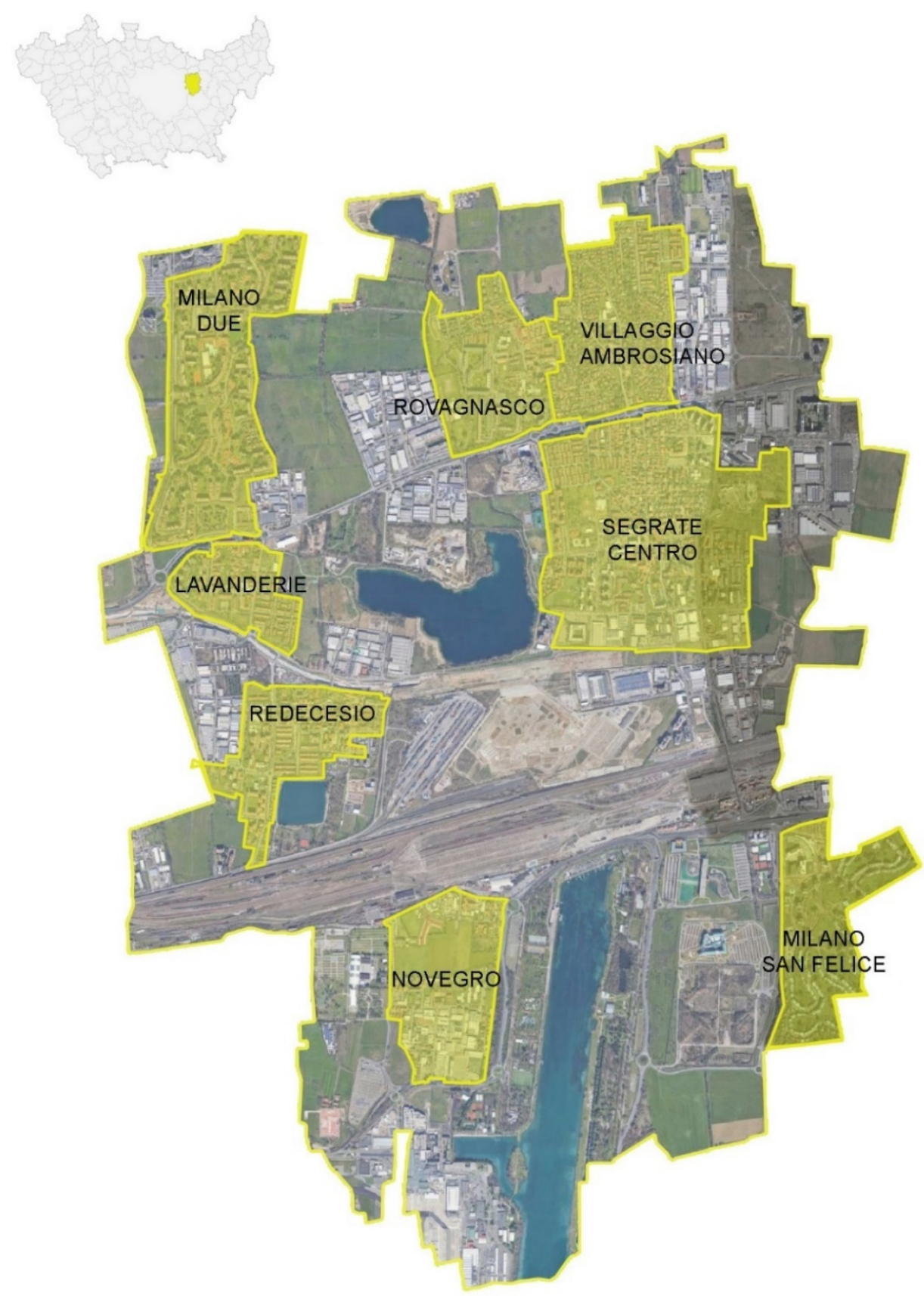

Figure 1. Study area: Segrate Municipality in the metropolitan area of Milan and its eight neighborhoods. 


\section{Segrate Energy Balance} actions:

The study of the neighborhoods' energy state allows carrying out three fundamental

- Assess the energy efficiency of the system;

- Highlight current trends and hypothesize short-medium-term forecasts;

- Identify the strategic intervention fields.

The analysis starts from the collection (in some cases from the estimate) of energy consumption data relating to the main urban functions: residential, productive, public administration, and tertiary. The commercial function is not considered separately, as there are no medium and large structures in these neighborhoods. There are only small commercial units and, although aware of the simplification, we associated them with domestic consumption. The obtained data will be expressed in $\mathrm{kWh} /$ year $\mathrm{m}^{2}$ (unit of measurement chosen to make a comparison between different functions; all data about inhabitants and urban functions dimensions are derived from the Segrate urban plan and related technical documents alongside numerical data downloaded from ISTAT and Geoportale of Lombardy Region [51,52]) and GWh/year for total consumption.

In relation to residential function, the average electricity consumption of a household depends on many factors, including the number of people living in the house, the time slot in which the occupants will be present in the house and will consume energy (for this function, the authors assume that the maximum energy use goes from 7 to 8 a.m. and from 7 to 11 p.m., considering the 8 working hours a day and other leisure's activities that keep people away from home); number and type of household appliances; house characteristics (i.e., year of constructions, type of structure, materials for wall, ceilings and windows); people's consumption habits.

According to the Regulatory Authority for Energy, Networks, and the Environment (Autorità di Regolazione per Energia Reti ed Ambiente, ARERA), a typical family has the following characteristics: $3-4$ members; $3 \mathrm{~kW}$ of power used in the house; $2700 \mathrm{kWh} /$ year (it should be noted that these are the values assumed by ARERA for every analysis on the consumption and costs trend of electricity in Italy) [53-55]. Aware that it is a simplification with respect to the variety and complexity of possible cases, it was decided to follow what is defined by ARERA using the higher annual consumption for each category.

Following these considerations, Table 1 presents the energy consumption in each Segrate neighborhood.

Table 1. Energy consumption and energy consumption per square meter for each Segrate neighborhood.

\begin{tabular}{ccccc}
\hline Neighborhoods & $\mathbf{N}^{\circ}$ Inhabitants & Total $\mathbf{~ m}^{\mathbf{2}}$ & $\begin{array}{c}\text { Energy Consumption } \\
\text { GWh/year }\end{array}$ & $\begin{array}{c}\text { Energy Consumption } \\
\mathbf{k W h} / \mathbf{y e a r} \mathbf{~ m}^{\mathbf{2}}\end{array}$ \\
\hline Segrate Centro & 11,556 & 577,800 & 13.972 & 24.1688 \\
Milano Due & 5950 & 297,500 & 7.278 & 24.4639 \\
Redecesio & 4926 & 246,300 & 6.0148 & 24.4206 \\
Rovagnasco & 3819 & 190,950 & 4.6245 & 24.2184 \\
San Felice & 2801 & 140,050 & 3.4266 & 24.467 \\
Villaggio Ambrosiano & 2798 & 139,900 & 3.2801 & 23.446 \\
Lavanderie & 2162 & 108,100 & 2.5662 & 23.7391 \\
Novegro & 2145 & 107,250 & 2.5706 & 23.9683 \\
TOT & 36,157 & $1,807,850$ & 43.7328 & - \\
\hline
\end{tabular}

From the analysis carried out, it emerges that the Segrate Centro neighborhood, as expected given its size and the massive presence of residences, is the largest consumer of electricity for domestic use. Furthermore, the average consumption is $24.19 \mathrm{kWh} /$ year $\mathrm{m}^{2}$ : the data remains constant for all the districts analyzed. 
As regards the heat carrier (the energy used for heat production that in Italy comes mainly from natural gas), using a general $150 \mathrm{kWh} /$ year $\mathrm{m}^{2}$., the following data are obtained (Table 2):

Table 2. Energy consumption for heat carrier for each Segrate neighborhood.

\begin{tabular}{cccc}
\hline Neighborhoods & N $^{\circ}$ Inhabitants & Total m $\mathbf{~}^{\mathbf{2}}$ & $\begin{array}{c}\text { Energy Consumption } \\
\text { GWh/year }\end{array}$ \\
\hline Segrate Centro & 11,556 & 577,800 & 86.67 \\
Milano Due & 5950 & 297,500 & 44.625 \\
Redecesio & 4926 & 246,300 & 36.945 \\
Rovagnasco & 3819 & 190,950 & 28.6425 \\
San Felice & 2801 & 140,050 & 21.0075 \\
Villaggio Ambrosiano & 2798 & 139,900 & 20.985 \\
Lavanderie & 2162 & 108,100 & 16.215 \\
Novegro & 2145 & 107,250 & 16.0875 \\
TOT & 36,157 & $1,807,850$ & 271.178 \\
\hline
\end{tabular}

As for the productive urban function, in the three neighborhoods, there are approximately $1658 \mathrm{~m}^{2}$. Considering the reference consumption data of 1,000,000 kWh/year (medium-sized company), we obtain 593,472 kWh/year $\mathrm{m}^{2}$.

The third function is related to public buildings: the Municipality of Segrate has an existing standard of $96.96 \mathrm{~m}^{2} /$ inhabitant, five times more than the law minimum (the Italian regulation imposes $18 \mathrm{~m}^{2} /$ inhabitant for urban public buildings and areas) [56] and in the three neighborhoods there are $55,604 \mathrm{~m}^{2}$ of public services. Knowing that the municipality consumes $6172.9 \mathrm{MWh}$ /year, we obtain a value equal to $105,562 \mathrm{kWh} /$ year $\mathrm{m}^{2}$.

Finally, only Segrate Centro neighborhood has tertiary buildings. For consumption, we rely on an ENEA [57] study concerning national electricity consumption divided by areas. To calculate the total consumption in Segrate Centro, we multiply the value of $155.51 \mathrm{kWh} /$ year $\mathrm{m}^{2}$ (supplied by ENEA) by the total square meters of the function $\left(25,592 \mathrm{~m}^{2}\right): 3.97 \mathrm{GWh} /$ year.

\section{Observations}

From the performed analysis, as Table 3 shows, it is highlighted that the largest amount of energy is consumed by the residential, which occupies $85 \%$ of the final consumption in the three neighborhoods with an average value of $174 \mathrm{kWh} /$ year $\mathrm{m}^{2}$. Please confirm you agree with this change., much higher than the other urban functions. The second position for consumption is taken by the industrial/productive sector, which occupies $11 \%$ of the total count and an average value of $391 \mathrm{kWh} /$ year $\mathrm{m}^{2}$. The public and tertiary sectors occupy a small part in the final consumption count and respectively record consumptions of 110 and $155 \mathrm{kWh} /$ year $\mathrm{m}^{2}$.

Table 3. Energy consumption in the different urban functions presented in the case study's neighborhoods.

\begin{tabular}{|c|c|c|c|c|c|c|c|}
\hline \multirow{2}{*}{$\begin{array}{l}\text { Urban } \\
\text { Function }\end{array}$} & \multicolumn{2}{|c|}{ Segrate Centro } & \multicolumn{2}{|c|}{ Villaggio Ambrosiano } & \multicolumn{2}{|c|}{ Rovagnasco } & \multirow{2}{*}{$\begin{array}{c}\text { TOT } \\
\text { GWh/year }\end{array}$} \\
\hline & GWh/year & $\mathrm{kWh} /$ year $\mathrm{m}^{2}$ & GWh/year & $\mathrm{kWh} /$ year $\mathrm{m}^{2}$ & GWh/year & $\mathrm{kWh} /$ year $\mathrm{m}^{2}$ & \\
\hline Residential & 100.64 & 174.2 & 24.26 & 173.4 & 33.27 & 174.2 & 158.17 \\
\hline Productive & 20.5 & 415.14 & - & - & 0.43 & 367.52 & 20.93 \\
\hline $\begin{array}{l}\text { Public } \\
\text { services }\end{array}$ & 2.9 & 87.1 & 0.31 & 115.1 & 1.2 & 119.2 & 4.41 \\
\hline Tertiary & 3.97 & 155.51 & - & - & - & - & 3.97 \\
\hline $\begin{array}{c}\text { TOT } \\
\text { GWh/year }\end{array}$ & 138.01 & & 24.57 & & 34.9 & & \\
\hline
\end{tabular}




\section{Results}

\subsection{Energy Potential in Segrate: Photovoltaic Resource}

For a gross municipality scale analysis, the calculation of photovoltaic (PV) production often implies estimates averages on an annual basis and on a territorial basis. Considering some system's standard operating conditions, it is, however, possible to make an approximate calculation of the photovoltaic production: generally, these Standard Test Conditions (STC) of operation define the orientation of the panels to the South, an inclination of 35 degrees, solar irradiation equal to $1000 \mathrm{Watt} / \mathrm{m}^{2}$, and a PV module temperature of 25 degrees centigrade. The authors use a simulator available online called PVGIS, with an interactive map curated by ESTI, European Solar Test Installation, a laboratory and research center of the European Commission on photovoltaics [58]. By entering data on system installation, the simulator, using an internal database on irradiation and productivity by type of photovoltaic panel and by installation area, allows making a quick calculation (in terms of time and ease of data entry) of the average production of the photovoltaic system.

The size of a $3 \mathrm{~kW}$ system is equivalent to $25 \mathrm{~m}^{2}$ of photovoltaic panels and is considered a system suitable for a family of 3-4 people, the one most purchased by condominiums and families: in Segrate, it produces $3766.31 \mathrm{kWh} /$ year.

Table 4 describes the necessary PV plants to cover all the energy needs of each neighborhood. It also shows the available space for the PV plant (authors only consider placing them on buildings' rooftop): in no case is the requirement totally satisfied by the production deriving only from PV panels. In particular, the \% PV column indicates the percentage of energy obtained from the photovoltaic panels with respect to the overall energy demand deriving from each urban function in a specific neighborhood (see Table 3).

Table 4. PV plant necessary and PV plant really placeable in the case study's neighborhoods.

\begin{tabular}{|c|c|c|c|c|c|c|}
\hline \multicolumn{7}{|c|}{ Segrate Centro } \\
\hline $\begin{array}{l}\text { Urban } \\
\text { Function }\end{array}$ & $\begin{array}{c}\mathrm{N}^{\circ} \text { Necessary } \\
\text { Plant }\end{array}$ & $\begin{array}{c}\text { Total } \\
\text { Necessary } \mathbf{m}^{2}\end{array}$ & $\begin{array}{c}\mathrm{m}^{2} \\
\text { Available }\end{array}$ & $\begin{array}{c}\mathrm{N}^{\circ} \text { Possible } \\
\text { Plants }\end{array}$ & $\begin{array}{l}\text { Production } \\
\text { GWh/year }\end{array}$ & $\% \mathrm{PV}$ \\
\hline Residential & 26,721 & 668,025 & 199,539 & 7981 & 30.06 & $29.87 \%$ \\
\hline Productive & 5443 & 136,075 & 49,380 & 1975 & 7.44 & $36.3 \%$ \\
\hline Public services & 770 & 19,250 & 18,381 & 735 & 2.77 & $95.51 \%$ \\
\hline Tertiary & 1054 & 26,350 & 6872 & 275 & 1.03 & $25.9 \%$ \\
\hline \multicolumn{7}{|c|}{ Villaggio Ambrosiano } \\
\hline $\begin{array}{l}\text { Urban } \\
\text { Function }\end{array}$ & $\begin{array}{c}\mathrm{N}^{\circ} \text { Necessary } \\
\text { Plant }\end{array}$ & $\begin{array}{c}\text { Total } \\
\text { Necessary } \mathbf{m}^{2}\end{array}$ & $\begin{array}{c}\mathrm{m}^{2} \\
\text { Available }\end{array}$ & $\begin{array}{c}\mathrm{N}^{\circ} \text { Possible } \\
\text { Plants }\end{array}$ & $\begin{array}{l}\text { Production } \\
\text { GWh/year }\end{array}$ & $\% \mathrm{PV}$ \\
\hline Residential & 6441 & 161,025 & 124,693 & 4987 & 18.78 & $77.4 \%$ \\
\hline Productive & - & - & - & - & - & - \\
\hline Public services & 83 & 2075 & 1347 & 53 & 0.2 & $64.5 \%$ \\
\hline Tertiary & - & - & - & - & - & - \\
\hline \multicolumn{7}{|c|}{ Rovagnasco } \\
\hline $\begin{array}{c}\text { Urban } \\
\text { Function }\end{array}$ & $\begin{array}{c}\mathrm{N}^{\circ} \text { Necessary } \\
\text { Plant }\end{array}$ & $\begin{array}{c}\text { Total } \\
\text { Necessary } \mathbf{m}^{2}\end{array}$ & $\begin{array}{c}\mathrm{m}^{2} \\
\text { Available }\end{array}$ & $\begin{array}{l}\mathrm{N}^{\circ} \text { Possible } \\
\text { Plants }\end{array}$ & $\begin{array}{l}\text { Production } \\
\text { GWh/year }\end{array}$ & $\% \mathrm{PV}$ \\
\hline Residential & 8833 & 220,825 & 46,926 & 1877 & 7.07 & $21.25 \%$ \\
\hline Productive & 114 & 2850 & 1170 & 46 & 0.17 & $39.44 \%$ \\
\hline Public services & 319 & 7975 & 6854 & 274 & 1.03 & $85.8 \%$ \\
\hline Tertiary & - & - & - & - & - & - \\
\hline
\end{tabular}

\subsection{Energy Potential in Segrate: Geothermal Energy Resource}

Introducing a low-temperature geothermal system and a geothermal heat pump it is possible to increase the production of renewable energy [59]. It uses the heat of the most superficial layers of soils (and of the aquifer that in Segrate is between 4 and $6 \mathrm{~m}$ under 
the ground level) to heat or cool buildings by means of heat pumps: it is a source of heat spread almost everywhere; therefore, it is easily used by the EC.

A correct evaluation of the geothermal plant, in terms of costs and benefits, must include the building's thermal energy needs; monovalent (heat pump only) or bivalent use (heat pump and other generators); type of soil available and plant option chosen; cost of radiators replacing with a low-temperature heating system; the degree of thermal insulation of the building and so on.

Table 5 shows the use of a generic low-temperature geothermal system for the heat vector (with a coefficient of performance, COP, equal to 4 ): there is a saving of $75 \%$ compared to the energy initially consumed by the thermal carrier for each sector.

Table 5. Energy consumption with a low-temperature geothermal system in the case study's neighborhoods.

\begin{tabular}{|c|c|c|c|c|c|c|}
\hline \multirow[b]{2}{*}{$\begin{array}{l}\text { Urban } \\
\text { Function }\end{array}$} & \multicolumn{2}{|c|}{ Segrate Centro } & \multicolumn{2}{|c|}{ Villaggio Ambrosiano } & \multicolumn{2}{|c|}{ Rovagnasco } \\
\hline & $\begin{array}{l}\text { Tot Energy } \\
\text { Consumption } \\
\text { GWh/year }\end{array}$ & $\begin{array}{c}\text { Energy } \\
\text { Consumption } \\
\text { with PV and } \\
\text { Geothermal } \\
\text { Resource } \\
\text { GWh/year }\end{array}$ & $\begin{array}{l}\text { Tot Energy } \\
\text { Consumption } \\
\text { GWh/year }\end{array}$ & $\begin{array}{c}\text { Energy } \\
\text { Consumption } \\
\text { with PV and } \\
\text { Geothermal } \\
\text { Resource } \\
\text { GWh/year }\end{array}$ & $\begin{array}{l}\text { Tot Energy } \\
\text { Consumption } \\
\text { GWh/year }\end{array}$ & $\begin{array}{c}\text { Energy } \\
\text { Consumption } \\
\text { with PV and } \\
\text { Geothermal } \\
\text { Resource } \\
\text { GWh/year }\end{array}$ \\
\hline Residential & 86.7 & 21.7 & 21 & 5.25 & 28.6 & 7.15 \\
\hline Productive & 20.5 & 5.1 & - & - & 0.43 & 0.11 \\
\hline Public services & 2.9 & 0.725 & 0.31 & 0.0775 & 1.2 & 0.3 \\
\hline Tertiary & 1.64 & 0.41 & - & - & - & - \\
\hline TOT & 111.74 & 27.93 & 21.31 & 5.33 & 30.23 & 7.56 \\
\hline$\%$ Saved & & $75 \%$ & & $75 \%$ & & $75 \%$ \\
\hline
\end{tabular}

Ultimately, the final requirement with the geothermal heat pump is shown in Table 6.

Table 6. Final energy consumption in each urban function in the case study's neighborhoods considering the use of PV and low-temperature geothermal system.

\begin{tabular}{cccc}
\hline Urban & Segrate Centro & $\begin{array}{c}\text { Villaggio } \\
\text { Ambrosiano }\end{array}$ & Rovagnasco \\
\cline { 2 - 4 } Function & $\begin{array}{c}\text { Total Consumption } \\
\text { GWh/year }\end{array}$ & $\begin{array}{c}\text { Total Consumption } \\
\text { GWh/year }\end{array}$ & $\begin{array}{c}\text { Total Consumption } \\
\text { GWh/year }\end{array}$ \\
\hline Residential & 35.672 & 13.78 & 18.9 \\
Productive & 5.1 & - & 0.11 \\
Public services & 0.725 & 0.0775 & 0.3 \\
Tertiary & 2.74 & - & - \\
TOT & 44.24 & 13.86 & 19.3 \\
\hline
\end{tabular}

\subsection{Production Balance and Electricity Needs}

In Table 7, the authors show the energy production and consumption with PV and the geothermal heat pump.

The final obtained results (Table 8) show that the energy demand is met, and, in some cases, there is a surplus of energy that can be used to cover any shortages in other areas of the neighborhoods. 
Table 7. PV plants necessary and PV plants really placeable in the case study's neighborhoods after the low-temperature geothermal system introduction.

\begin{tabular}{|c|c|c|c|c|c|c|c|}
\hline \multicolumn{8}{|c|}{ Segrate Centro } \\
\hline $\begin{array}{c}\text { Urban } \\
\text { Function }\end{array}$ & $\begin{array}{c}\mathrm{N}^{\circ} \text { Necessary } \\
\text { Plant }\end{array}$ & $\begin{array}{c}\text { Total Necessary } \\
\text { m }^{2}\end{array}$ & $\begin{array}{c}\mathbf{m}^{2} \\
\text { Available }\end{array}$ & $\begin{array}{l}\mathrm{N}^{\circ} \text { Possible } \\
\text { Plants }\end{array}$ & $\begin{array}{l}\text { Production } \\
\text { GWh/year }\end{array}$ & $\%$ PV & \% Surplus \\
\hline Residential & 9472 & 236,800 & 199,539 & 7981 & 30.06 & $84.3 \%$ & - \\
\hline Productive & 1355 & 10,840 & 49,380 & 1975 & 7.44 & $145.9 \%$ & $46 \%$ \\
\hline $\begin{array}{l}\text { Public } \\
\text { services }\end{array}$ & 193 & 4825 & 18,381 & 735 & 2.77 & $382 \%$ & $282 \%$ \\
\hline Tertiary & 728 & 18,200 & 6872 & 275 & 1.03 & $37.66 \%$ & - \\
\hline \multicolumn{8}{|c|}{ Villaggio Ambrosiano } \\
\hline $\begin{array}{c}\text { Urban } \\
\text { Function }\end{array}$ & $\begin{array}{c}\mathrm{N}^{\circ} \text { Necessary } \\
\text { Plant }\end{array}$ & $\begin{array}{c}\text { Total Necessary } \\
\text { m }^{2}\end{array}$ & $\mathrm{~m}^{2}$ Available & $\begin{array}{l}\mathbf{N}^{\circ} \text { Possible } \\
\text { Plants }\end{array}$ & $\begin{array}{l}\text { Production } \\
\text { GWh/year }\end{array}$ & $\% \mathrm{PV}$ & \% Surplus \\
\hline Residential & 3659 & 91,475 & 124,693 & 4987 & 18.78 & $136 \%$ & $36 \%$ \\
\hline Productive & - & - & - & - & - & - & - \\
\hline $\begin{array}{l}\text { Public } \\
\text { services }\end{array}$ & 21 & 525 & 1347 & 53 & 0.2 & $258 \%$ & $158 \%$ \\
\hline Tertiary & - & - & - & - & - & - & - \\
\hline \multicolumn{8}{|c|}{ Rovagnasco } \\
\hline $\begin{array}{c}\text { Urban } \\
\text { Function }\end{array}$ & $\begin{array}{c}\mathrm{N}^{\circ} \text { Necessary } \\
\text { Plant }\end{array}$ & $\begin{array}{c}\text { Total Necessary } \\
\text { m }^{2}\end{array}$ & $\mathrm{~m}^{2}$ Available & $\begin{array}{l}\mathrm{N}^{\circ} \text { Possible } \\
\text { plants }\end{array}$ & $\begin{array}{l}\text { Production } \\
\text { GWh/year }\end{array}$ & $\% \mathrm{PV}$ & \% Surplus \\
\hline Residential & 5019 & 125,475 & 46,926 & 1877 & 7.07 & $37.4 \%$ & - \\
\hline Productive & 30 & 240 & 1170 & 46 & 0.17 & $154 \%$ & $54 \%$ \\
\hline $\begin{array}{l}\text { Public } \\
\text { services }\end{array}$ & 80 & 2000 & 6854 & 274 & 1.03 & $400 \%$ & $300 \%$ \\
\hline Tertiary & - & - & - & - & - & - & - \\
\hline
\end{tabular}

Table 8. Final energy balance in the case study's neighborhoods.

\begin{tabular}{|c|c|c|c|c|}
\hline \multicolumn{5}{|c|}{ Segrate Centro } \\
\hline $\begin{array}{l}\text { Urban } \\
\text { Function }\end{array}$ & $\begin{array}{l}\text { Production } \\
\text { GWh/year }\end{array}$ & $\begin{array}{c}\text { Needs } \\
\text { GWh/year }\end{array}$ & Balance & TOT \\
\hline Residential & 30.06 & 35.672 & -5.612 & \\
\hline Productive & 7.44 & 5.1 & +2.34 & \\
\hline Public services & 2.77 & 0.725 & +2.045 & -2.93 \\
\hline Tertiary & 1.032 & 2.74 & -1.708 & \\
\hline \multicolumn{5}{|c|}{ Villaggio Ambrosiano } \\
\hline $\begin{array}{l}\text { Urban } \\
\text { Function }\end{array}$ & $\begin{array}{l}\text { Production } \\
\text { GWh/year }\end{array}$ & $\begin{array}{c}\text { Needs } \\
\text { GWh/year }\end{array}$ & Balance & TOT \\
\hline Residential & 18.78 & 13.78 & +5 & \\
\hline Productive & - & - & - & \\
\hline Public services & 0.2 & 0.0775 & +0.1225 & +5.12 \\
\hline Tertiary & - & - & - & \\
\hline \multicolumn{5}{|c|}{ Rovagnasco } \\
\hline $\begin{array}{c}\text { Urban } \\
\text { Function }\end{array}$ & $\begin{array}{l}\text { Production } \\
\text { GWh/year }\end{array}$ & $\begin{array}{c}\text { Needs } \\
\text { GWh/year }\end{array}$ & Balance & TOT \\
\hline Residential & 7.07 & 18.9 & -11.8 & \\
\hline Productive & 0.17 & 0.11 & +0.06 & \\
\hline Public services & 1.2 & 0.3 & +0.9 & -10.8 \\
\hline Tertiary & - & - & - & \\
\hline
\end{tabular}




\subsection{Segrate Neighborhoods as a Unique Energy Island: Energy Exchanges}

The presented research shows an energy deficit in each neighborhood but in different urban functions. As regards Segrate Centro, the industrial and public sectors have a production surplus compared to their own needs, Villaggio Ambrosiano has a production higher than its consumption; finally, Rovagnasco has a surplus in the industrial and public sector. Table 7 shows the negative balance in the residential sector as regards Rovagnasco, this is due to the massive presence of tall buildings (tower or multi-storey) that include a conisderable number of inhabitants, but the area available to produce energy from PV on the rooftops is limited; on the other hand, the opposite case is the neighborhood of Villaggio Ambrosiano, occupied almost entirely by single houses and villas in which the area for $\mathrm{PV}$ is higher.

The peculiar neighborhood urban fabric, together with the specific functions, determines the distribution of supply and demand of energy (see Table 8).

These excesses of energy deriving from the different urban functions can be exchanged inside each neighborhood to cover its own needs, then in the three surrounding neighborhoods, and finally, with other urban districts. Segrate already has a public/private network of underground utilities (for electricity, heating systems, gas, water abduction, sewer, telecommunications-PUGSS) [50] connecting the users, so to allow the energy exchanges and the creation of an effective and efficient Energy Island, it is possible to: take advantage of the network that already exists, or establish a new and ad hoc network with higher performance. Both hypotheses have positive and negative sides: the first is more advantageous from an economic point of view, but at the same time, it would be necessary to adapt to existing and often old networks, the second hypothesis offers the possibility of designing networks that are better suited to each island, but on the other hand, it involves a much higher cost and difficulties in the construction phase.

Assuming, for ease of intervention, to use the existing network, Segrate has a welldistributed network of underground services and technical buildings within the three neighborhoods. Figure 2 shows the underground and overhead electricity grid of Segrate with the 380 and $15 \mathrm{kV}$, also indicating the external electrical substations.

Now, based on the hypothesis of energy exchange through existing networks, aware of the energy timeframe for each urban functions, considering that the residential sector will need more energy than its production and that the industrial and public sectors will have a surplus, this surplus can be accumulated and used in the residential sector inside each neighborhood. Moreover, the only neighborhood that will exchange energy with others is Villaggio Ambrosiano: it is the only one with surplus energy and no other internal functions to compensate. Segrate Centro and Rovagnasco also have a surplus but will use it for the residential sector, which has a negative balance [50,52]. 


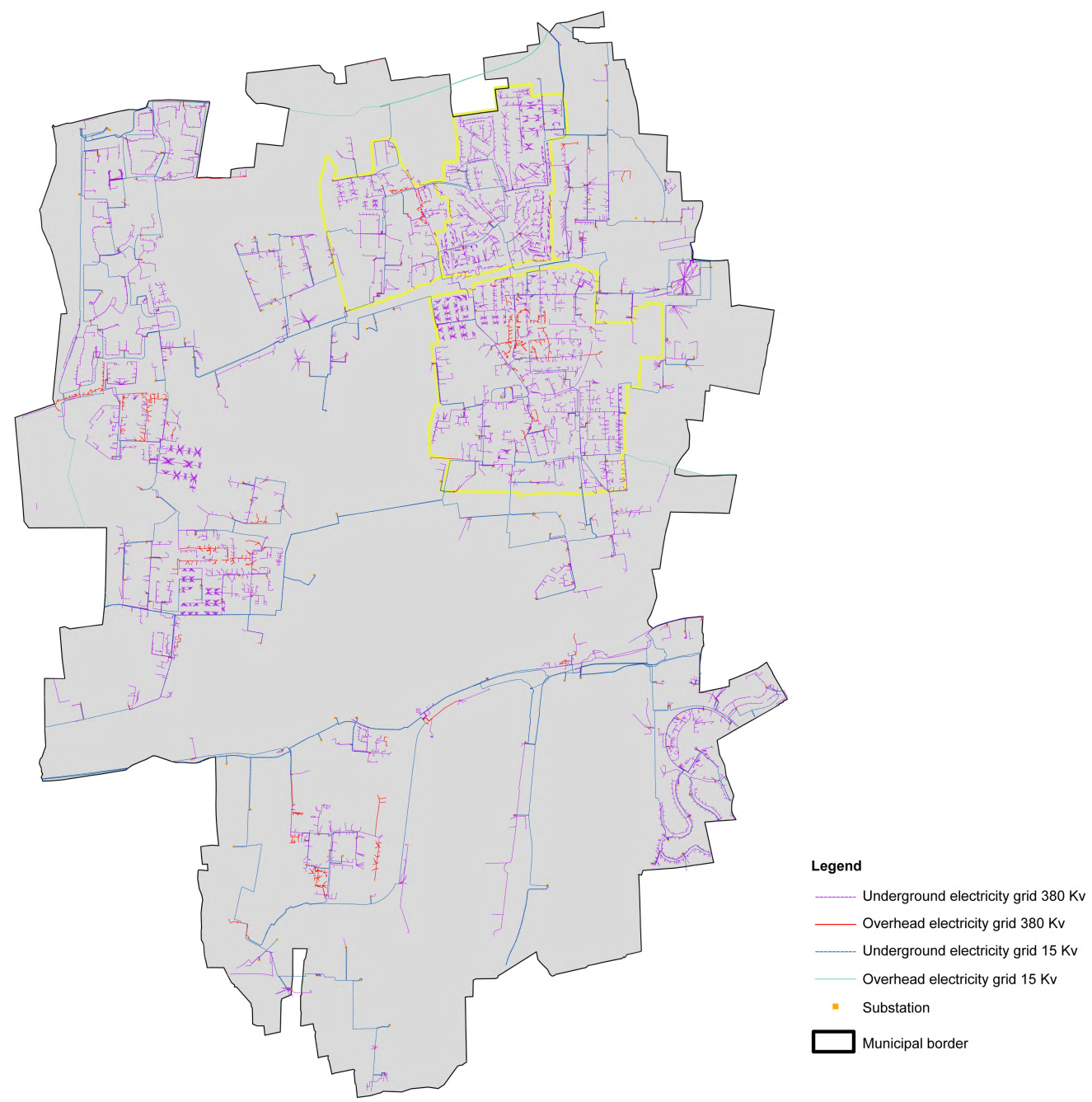

Figure 2. Underground and overhead electricity grid of Segrate Municipality. The three selected neighborhoods are highlighted (Segrate Centro, Villaggio Ambrosiano, and Rovagnasco).

\section{Discussion}

Nowadays, in many European countries, Energy Communities may transform the future energy market, representing a significant share of investments in renewables, helping to revitalize the local economy and creates jobs. For what emerged in the paper, at the European level, with a specific and supportive legal framework, CEC and REC can flourish and provide a major share of energy (renewable or not), and thus significantly contribute to energy system optimization and to the decarbonization of the old continent. In Italy, it is important to recognize Energy Communities as factual realities. Specific policies must be defined to promote the CEC and REC within the municipality's energy plans [60]. The aim is to ensure a balanced level among the prosumers and the comprehensive energy market. From the organizational point of view, ECs assume a role for the inclusion strategies; to ease the creation and to support the trust in the community, the basis is the creation of open access information and regulations tools [35,61].

In recent years, Energy Communities have been studied from many points of view. Few studies were on the motivations behind the direct and active participation of citizens in the production and distribution of energy or even on the will to invest their financial resources in these kinds of projects. Economic, environmental, social, political, and technological are the most important motivations, along with the concern about the fundamentals of energy policies (decentralization and energy self-sufficiency). All these aspects can become conflict points and can cause difficulties in the EC's definition and development [62,63]. 
Going into detail for each involved aspect, here are a series of pros and cons deriving from the case of Segrate, but which can be extended to different contexts. Among the cons, some barriers to the implementation of CE have been identified [64,65]. Considering the existing situation of a private and not shared energy system, there are factual barriers regarding legal and technical aspects and socio-psychological barriers associated with the attitudes of potential EC participants:

- Economic aspect. PRO: incentives to produce renewable energy; profits due to the sale of energy and savings due to self-production; independence from the oil/gas giants. CONS: initial costs to start the project related to energy infrastructure and plant maintenance and management; payback time for initial costs [66];

- Social aspect. PRO: investments derived from profits for infrastructure, services, and an enhancement of life quality for the community; greater protection. CONS: massive informational/educational campaigns for the community; reaching of common agreements among the interested parties; a general lack of awareness and environmental concerns; cultural negative stereotypes regarding collective ownership [67]; resistance to change and desire to maintain the status quo; level of education and gender [68];

- Technical aspect. PRO: less complexity of process management due to relatively small spatial dimensions of selected potential communities and islands; on-site production of energy; possible exploitation of existing municipal network; faster development of technologies related to renewable energy sources. CONS: efficiency of the system "buildings + energy network" in fabrics with lower energy classes; plant maintenance; design of new infrastructures to adapt the project to users' needs; production capacity; lack of ground or space to put PV panels [69,70];

- Legal/juridical aspect. PRO: existence of European regulations and laws that encourage the production of energy from renewable sources; incentives for the development of energy efficiency and saving of industrial and residential buildings. CONS: lack of alignment between European directives and Member States; procedural timing; coordination among involved entities (state, province, municipal, private); difficulty in obtaining access to green energy certificate [63,71-73];

- Environmental aspect. PRO: use of renewables for energy production in order to reduce pollution; independence from fossil fuels (at least partial). CONS: life cycle assessment of technical devices (i.e., PV cells and panels).

\subsection{Administrative Burden}

According to the Italian legal framework (please see Section 2.2 above), the creation of an Energy Community may face material and procedural obstacles. For the sake of clarity, we identified three main phases in which the implementation process of an energy production plant through the community model may be divided; each of them is affected by the specific criticalities, which mainly refers to the involved public authorities. The phases are: planification and authorization of the construction of the energy system (phase 1); connection of the plant and Energy Community accreditation with the GSE (phase 2); energy remuneration by the GSE (phase 3).

Phase 1: planification and authorization of the construction of the energy system.

At this stage, the main obstacles involve the authorization process and urban planning procedure that must be followed to build the energy system. Project approval usually takes a considerable amount of time, which may increase both (i) when an amendment to the existing town plan is required, or (ii) if environmental or cultural interests are involved; in any case, the 90 or 180 days prescribed as the deadline of the single procedure in the national law on administrative procedure [74] may be suspended for 90 days-one time only-pending a technical assessment to be rendered by another authority within the same procedure. Furthermore, the installation of an energy plant across the territories governed by two or more municipalities or regions causes a proliferation of the involved authorities that may increase the complexity of the procedure, with possible repercussions on the timing of its conclusion when there is no agreement or in the case of real conflict. 
For those reasons, recent national legislative acts amended the authorization procedures regarding renewable energies plants, providing for a simplified procedure into which the public authority entitled with the final decision (e.g., the Minister of Ecologic Transition or a Region) can reasonably overtake the negative opinion on the project rendered by cultural and landscape local authority (Soprintendenza); that is allowed when the project indirectly involves the landscape or cultural interest. Moreover, Article 22 of Legislative Decree No. 199/2021 (see Section 2.3 above) applies the same regime (non-binding opinion of the Soprintendenza) to the renewable plants located in those areas identified as "Suitable" with Regional Law, even if the landscape or cultural interests may be directly compromised by the energy plant [41].

That said, however, until the area selected for the project realization is not expressly qualified as "Suitable" by law, three administrative hurdles can still be identified:

- Plurality of additional administrative competences: while the municipality is ordinarily competent for the issuance of the building permit, other local bodies (e.g., province or region) or central state entities (e.g., Minister of the Ecologic Transition) may be involved depending on the entity and position of the plants. As already mentioned, if the proposed project potentially affects a landscape or cultural interest, the consent of the Ministry of Cultural Heritage or of the Soprintendenza is mandatorily required [75-77];

- Prevalence of the environmental interest over that of the development of renewable energy: practical experience shows that many requests for the construction of photovoltaic systems are rejected due to the prevalence of environmental protection;

- Prevalence of cultural interest over that of the development of renewable energy: the system's construction finds a further hurdle to the need to respect the numerous historical, landscape, and cultural ties present on buildings.

Phase 2: connection of the plant and Energy Community accreditation with the GSE. Once the system is built so that the community becomes operational, a new bureaucratic process managed by the GSE must be followed. The analysis of the formal profiles of the procedure highlights two potentials obstacles:

- $\quad$ Required documentation: it is very extensive and incompatible with the open character of the community, since it also prescribes, in addition to the usual requirements, the mandates of the final customers (which, therefore, must be predetermined);

- Informatic complication: two informatic portals coexist (the "Gaudi" portal run by Terna S.p.A. and another portal run by the GSE), with respect to which the second does not allow to change the data of the first, causing excessive rigidity [78].

Phase 3: energy remuneration by the GSE.

At this last stage, examining technical documentation already adopted, we can only assume one purely bureaucratic hurdle, i.e., the need to provide the GSE with a lot of data and documentation, lacking which it is not possible to obtain any remuneration for the produced energy.

\subsection{Urban Policies in the City Plan}

In the Lombardy Region context, the regulatory framework about city planning is based on the law 11 March 2005 n.12 that introduced a new city plan model, called Territorial Government Plan (Piano di Governo del Territorio, PGT) [79]. This plan is divided into three documents: the strategic component (Documento di Piano, DDP), the public city government (Piano dei Servizi. PDS), and the private city and normative system (Piano delle Regole, PDR). Moreover, the infrastructural system is analyzed and forecasted in a sectorial plan called "Plan for the underground services" (Piano urbano generale dei servizi del sottosuolo, PUGSS). A sectoral plan regarding mobility, the Sustainable Mobility Plan (Piano Urbano della Mobilità Sostenibile, PUMS), defines the general strategies about sustainable mobility and addresses the practical design of soft mobility and of the urban road system and cyclable paths. 
The Energy Communities and the Energy Islands, in Segrate Municipality, have to deal with the city plan structure and their prevision and organizational structure need to be coherent at least for the following aspects:

- Urban fabric and urban functions: DDP and PDR (the DDP has influence for the general strategies about energy, for the new settlements or regeneration area; the PDR has influence in the local and private management);

- $\quad$ Infrastructural system: PUGSS (all the network connections are defined according to this document);

- Mobility issues: PUMS;

- $\quad$ Recharge stations, technological infrastructure, energy cabins: PDS and PUGSS (PDS for the public area management, PUGSS for the infrastructural system).

About the organization system, the Italian legal framework on the organization of local authorities (Legislative Decree of 18 August 2000 No. 267) [80] defines the responsibilities of each bureau with a political or technical role. For every practical action that is coherent with the city plan (PGT), there is only the technical passage; for actions that require a modification of the city plan or that imply a public-private agreement, political intervention is needed. As it is well known, a public-private agreement is possible only when public advantages are clear; surely, a new way of managing energy in the private sector has public returns in terms of increasing sustainable behaviors. A stronger public return could be reached involving the Energy Island not only in private sectors (buildings and mobility means) but also public ones (for example, public services).

For the Energy Communities, the actual state-of-the-art of local planning in Italy is not generally updated, so there is the necessity to provide specific projects that imply the public intervention at the technical level and at the political level. Therefore, the new policies need at least four main passages:

- Legal examination;

- $\quad$ City planning proposal (with or without modification of the existing planning documents);

- Technical and implementational phases definition;

- Approval steps (public-private agreement).

Usually, these four steps require a certain quantity of time (the order of magnitude of the procedure is legally some months, but in Italy, it is more credible to figure at least one year, also considering the non-binding nature of many terms) and much technical expertise that could interfere with the organizational and social aspects, more than with the economic balance.

\section{Conclusions}

Considering the current situation of urban development and its trends for the future, the rapid consumption of non-renewable raw materials and the need to improve and maintain a high level of life quality for citizens, the most important concept related to energy in cities is to achieve its sustainable form, which stems from optimal energy efficiency.

Energy Communities, starting from the voluntary organization of collective and citizen-driven energy actions, help to increase the citizens' acceptance of renewable energy projects, contribute to attracting private investments in the clean energy transition, provide direct benefits to people, such as lowering electricity bills, help in providing flexibility to the electricity system through demand-response and storage, and, at the same time, contribute to reducing energy consumption.

The European energy market is experiencing a fundamental transition from fossil resource energy to renewable resource, efficient, and sustainable energy; it is also transforming from a centralized market with only large isolated plants to a distributed one, with millions of active citizens. Europe considers citizens as the real core of its energy transition process, and this is essential for its success.

The next step of the research is to define practices, in the specific case of Segrate, the main drivers and barriers in the realization of the Energy Islands. Some neighborhoods, 
such as Milano Due and San Felice, were designed in a unitary way with a unique heating system; so, the inhabitants are already prepared for this challenge. New neighborhoods are planned and under construction with specific unitary heating and cooling systems, so the future inhabitants will participate in new Energy Islands. The greatest problems emerge in the existing city where no energy rule was defined in the building period and in which private owners manage the private property independently with contracts with the public or private energy management institutions (for example, the national electrical greed management system). The fragmentation of the actual property system, controlled by big companies that have an economic advantage in furnishing the energy directly to the individual owner, is the hardest barrier to overcome. The individual behaviors and expectations, the psychological aspects, the organizational constraints, and degrees of freedom seem to be more difficult to solve than the strictly technical aspects.

Author Contributions: Conceptualization, E.M.V. and R.D.L.; methodology, E.M.V.; software, E.M.V.; validation, E.M.V. and R.D.L.; formal analysis, R.D.L.; investigation, C.M., A.B. and R.D.N.; resources, C.M., A.B. and R.D.N.; data curation, R.D.L. and E.M.V.; writing-original draft preparation, E.M.V.; writing-review and editing, E.M.V. and C.M.; visualization, E.M.V.; supervision, R.D.L. and C.M.; project administration, R.D.L. and E.M.V.; funding acquisition, R.D.L. All authors have read and agreed to the published version of the manuscript.

Funding: This research was funded by the European Union HORIZON 2020 Project-H2020-LC-SC32018-2019-2020; project title: “RENergetic: Community-empowered Sustainable Multi-Vector Energy Islands"; grant number/ID project: 957845.

Institutional Review Board Statement: Not applicable.

Informed Consent Statement: Not applicable.

Data Availability Statement: Not applicable.

Conflicts of Interest: The authors declare no conflict of interest. The funders had no role in the design of the study; in the collection, analyses, or interpretation of data; in the writing of the manuscript, or in the decision to publish the results.

\section{References}

1. IEA (International Energy Agency). World Energy Outlook-Topics-IEA. 2019. Available online: https://www.iea.org/topics/ world-energy-outlook (accessed on 7 February 2022).

2. Worldmeter. Real Time World Statistics. Available online: https:/ /www.worldometers.info/ (accessed on 7 February 2022).

3. Lin, B.; Du, Z. How China's urbanization impacts transport energy consumption in the face of income disparity. Renew. Sustain. Energy Rev. 2015, 52, 1693-1701. [CrossRef]

4. Maparu, T.S.; Mazumder, T.N. Transport infrastructure, economic development and urbanization in India (1990-2011): Is there any causal relationship? Transp. Res. Part A Policy Pract. 2017, 100, 319-336. [CrossRef]

5. Sehrawat, M. Modelling the nexus between human capital, income inequality, and energy demand in India: New evidences from asymmetric and non-linear analysis. Environ. Sci. Pollut. Res. 2021, 28, 3632-3643. [CrossRef] [PubMed]

6. IEA (International Energy Agency). World Energy Outlook-Topics_IEA. 2021. Available online: https://www.iea.org/topics/ world-energy-outlook (accessed on 7 February 2022).

7. Mohanty, B. Sustainable Urban Energy - A Source Book for Asia; Barth, B., Cabrera, F., Rollnick, R., Eds.; United Nations Human Settlements Programme (UN HABITAT): Nairobi, Kenya, 2012.

8. Gestore Servizi Energetici (GSE). Monitoraggio dei Target Nazionali e Regionali. Fonti Rinnovabili in Italia e Nelle Regioni 2012-2019. 2021. Available online: https://www.gse.it/documenti_site/Documenti\%20GSE/Rapporti\%20statistici/Rapporto\% 20statistico\%20di\%20monitoraggio\%20di\%20cui\%20al\%20DM\%2011-5-15\%20art\%207_anni\%202012-2019.pdf (accessed on 18 December 2021).

9. European Commission. SWD (2015) 141 Final: Best Practices on Renewable Energy Self-Consumption; European Commission: Brussels, Belgium, 2015.

10. European Commission. COM (2021) 950 Final: Report from the Commission to the European Parliament, the Council, the European Economic and Social Committee and the Committee of the Regions. State of the Energy Union 2021-Contributing to the European Green Deal and the Union's Recovery (Pursuant to Regulation (EU) 2018/1999 on the Governance of the Energy Union and Climate Action); European Commission: Brussels, Belgium, 2021. 
11. Barroco, F.; Cappellaro, F.; Palumbo, C. (Eds.) Le Comunità Energetiche in Italia. Una Guida per Orientare i Cittadini nel Nuovo Mercato Dell'energia; Progetto Europeo GECO cofinanziato da EIT Climate: 2020. Available online: https://www.enea.it/it/ seguici/pubblicazioni/pdf-volumi/2020/guida_comunita-energetiche.pdf (accessed on 10 December 2021).

12. Wierling, A.; Zeiss, J.P.; Lupi, V.; Candelise, C.; Sciullo, A.; Schwanitz, V.J. The contribution of energy communities to the upscaling of photovoltaics in Germany and Italy. Energies 2021, 14, 2258. [CrossRef]

13. Borowski, P.F. Zonal and nodal models of energy market in European union. Energies 2020, 13, 4182. [CrossRef]

14. Espe, E.; Potdar, V.; Chang, E. Prosumer communities and relationships in smart grids: A literature review, evolution and future directions. Energies 2018, 11, 2528. [CrossRef]

15. Milčiuvienè, S.; Kiršienè, J.; Doheijo, E.; Urbonas, R.; Milčius, D. The role of renewable energy prosumers in implementing energy justice theory. Sustainability 2019, 11, 5286. [CrossRef]

16. Brunetta, G.; Moroni, S. Contractual Communities in the Self-Organising City: Freedom, Creativity, Subsidiarity; Springer: Berlin, Germany, 2012.

17. Directive (EU) 2018/2001 of the European Parliament and of the Council of 11 December 2018 on the Promotion of the Use of Energy from Renewable Sources. Available online: https:/ / eur-lex.europa.eu/legal-content/EN/TXT/PDF/?uri=CELEX: 32018L2001\&from $=$ fr (accessed on 12 December 2021).

18. Directive (EU) 2019/944 of the European Parliament and of the Council of 5 June 2019 on Common Rules for the Internal Market for Electricity and Amending Directive 2012/27/EU. Available online: https:/ / eur-lex.europa.eu/legal-content/EN/TXT/PDF/ ?uri=CELEX:32019L0944 (accessed on 12 December 2021).

19. Cielo, A.; Margiaria, P.; Lazzeroni, P.; Mariuzzo, I.; Repetto, M. Renewable energy communities business models under the 2020 Italian regulation. J. Clean. Prod. 2021, 316, 128217. [CrossRef]

20. Moroni, S.; Alberti, V.; Antoniucci, V.; Bisello, A. Energy communities in a distributed-energy scenario: Four different kinds of community arrangements. In Smart and Sustainable Planning for Cities and Regions; Bisello, A., Vettorato, D., Laconte, P., Costa, S., Eds.; Springer International Publishing: Cham, Switzerland, 2018; pp. 429-437.

21. Moroni, S.; Alberti, V.; Antoniucci, V.; Bisello, A. Energy communities in the transition to a low-carbon future: A taxonomical approach and some policy dilemmas. J. Environ. Manag. 2019, 236, 45-53. [CrossRef]

22. Ecker, F.; Spada, H.; Hahnel, U.J. Independence without control: Autarky outperforms autonomy benefits in the adoption of private energy storage systems. Energy Policy 2018, 122, 214-228. [CrossRef]

23. Reis, I.F.; Gonçalves, I.; Lopes, M.A.; Antunes, C.H. Assessing the influence of different goals in energy communities' selfsufficiency. An optimised multiagent approach. Energies 2021, 14, 989. [CrossRef]

24. Directive 2001/77/EC of the European Parliament and of the Council of 27 September 2001 on the Promotion of Electricity Produced from Renewable Energy Sources in the Internal Electricity Market. Available online: https://eur-lex.europa.eu/ LexUriServ/LexUriServ.do?uri=OJ:L:2001:283:0033:0040:EN:PDF (accessed on 7 February 2022).

25. Directive 2003/30/EC of the European Parliament and of the Council of 8 May 2003 on the Promotion of the Use of Biofuels or Other Renewable Fuels for Transport. Available online: https:/ / eur-lex.europa.eu/legal-content/EN/TXT/PDF/?uri=CELEX: 32003L0030\&from $=$ en (accessed on 7 February 2022).

26. Directive 2009/28/EC of the European Parliament and of the Council of 23 April 2009 on the Promotion of the Use of Energy from Renewable Sources and Amending and Subsequently Repealing Directives 2001/77/EC and 2003/30/EC. Available online: https:/ / eur-lex.europa.eu/LexUriServ/LexUriServ.do?uri=OJ:L:2009:140:0016:0062:en:PDF (accessed on 11 December 2021).

27. Hoicka, C.; Lowitzsch, J.; Brisbois, M.C.; Kumar, A.; Ramirez Camargo, L. Implementing a just renewable energy transition: Policy advice for transposing the new European rules for renewable energy communities. Energy Policy 2021, 156, 112435. [CrossRef]

28. Ministero dello Sviluppo Economico; Ministero dell'Ambiente e della Tutela del Territorio e del Mare; Ministero delle Infrastrutture e dei Trasporti. Piano Nazionale Integrato per l'Energia e il Clima. 2019. Available online: https://www.mise.gov.it/images / stories/documenti/PNIEC_finale_17012020.pdf (accessed on 7 February 2022).

29. Piano Nazionale di Ripresa e Resilienza, PNRR. Home-Italia Domani-NRRP Portal. Available online: https:/ /italiadomani. gov.it/en/home.html (accessed on 20 December 2021).

30. Lowitzsch, J.; Hoicka, C.E.; van Tulder, F.J. Renewable energy communities under the 2019 European Clean Energy PackageGovernance model for the energy clusters of the future? Renew. Sustain. Energy Rev. 2020, 122, 109489. [CrossRef]

31. Abada, I.; Ehrenmann, A.; Lambin, X. On the viability of energy communities. Energy J. 2020, 41, 113-150. [CrossRef]

32. Barroco Fontes Cunha, F.; Carani, C.; Nucci, C.A.; Castro, C.; Santana Silva, M.; Torres, E.A. Transitioning to a low carbon society through energy communities: Lessons learned from Brazil and Italy. Energy Res. Soc. Sci. 2021, 75, 101994. [CrossRef]

33. Berka, A.; Dreyfus, M. Decentralisation and inclusivity in the energy sector: Preconditions, impacts and avenues for further research. Renew. Sustain. Energy Rev. 2021, 138, 110663. [CrossRef]

34. Schäfer, M.; Hielscher, S.; Haas, W.; Hausknost, D.; Leitner, M.; Kunze, I.; Mandl, S. Facilitating low-carbon living? A comparison of intervention measures in different community-based initiatives. Sustainability 2018, 10, 1047. [CrossRef]

35. Caramizaru, A.; Uihlein, A. Energy Communities: An Overview of Energy and Social Innovation; Publications Office of the European Union: Luxembourg, 2020.

36. Moroni, S.; Antoniucci, V.; Bisello, A. Local energy communities and distributed generation: Contrasting perspectives, and inevitable policy trade-offs, beyond the apparent global consensus. Sustainability 2019, 11, 3493. [CrossRef] 
37. European Commission. Energy Communities. Available online: https://ec.europa.eu/energy/topics/markets-and-consumers/ energy-communities_en (accessed on 20 December 2021).

38. Heldeweg, M.A.; Saintier, S. Renewable energy communities as 'socio-legal institutions': A normative frame for energy decentralization? Renew. Sustain. Energy Rev. 2020, 119, 109518. [CrossRef]

39. Walker, G.; Hunter, S.; Devine-Wright, P.; Evans, B.; Fay, H. Harnessing community energies: Explaining and evaluating community-based localism in renewable energy policy in the UK. Glob. Environ. Politics 2007, 7, 64-82. [CrossRef]

40. Verde, S.F.; Rosetto, N.; Ferrari, A.; Fonteneau, T. The Future of Renewable Energy Communities in the EU. An Investigation at the Time of the Clean Energy Package. Re-search Report. 2020. Available online: https://cadmus.eui.eu/bitstream/handle/1814 /68383/QM-04-20-447-EN-N.pdf?sequence=1 (accessed on 5 December 2021).

41. Legislative Decree No. 199/2021. Available online: https://www.gazzettaufficiale.it/eli/id/2021/11/30/21G00214/sg (accessed on 3 February 2022).

42. ARERA Resolution of 4 August 2020, No. 318/2020/R/eel; Decree of Minister for Economic Development of 19 September 2020. Available online: https://www.mercatoelettrico.org/En/gme/Info/normative.aspx?val=Normativa1.htm (accessed on 1 February 2022).

43. Senato della Repubblica. Promozione dell'uso dell'energia da fonti rinnovabili. Available online: https://www.senato.it/leg/18 /BGT/Schede/docnonleg/43114.htm (accessed on 5 February 2022).

44. REScoop MECISE, Mobilising European Citizens to Invest in Sustainable Energy, Clean Energy for All Europeans, Final Results Oriented Report of the RESCOOP MECISE Horizon 2020 Project. 2019. Available online: https://www.rescoop-mecise.eu/ (accessed on 2 February 2022).

45. Mutani, G.; Todeschi, V.; Santantonio, S.; Bazzino, M. Energy communities a new energy policy at territorial scale. Energy Sustain. Int. Conf. 2019, 24, 26.

46. Ufficio Energia Legambiente. Comunità Rinnovabili 2021. Available online: https://www.legambiente.it/wp-content/uploads/ 2021/07/Comunita-Rinnovabili-2021.pdf (accessed on 16 December 2021).

47. Wierling, A.; Schwanitz, V.J.; Zeiß, J.P.; Bout, C.; Candelise, C.; Gilcrease, W.; Sterling Gregg, J. Statistical evidence on the role of energy cooperatives for the energy transition in European countries. Sustainability 2018, 10, 3339. [CrossRef]

48. Di Silvestre, M.L.; Ippolito, M.G.; Riva Sanseverino, E.; Sciumè, G.; Vasile, A. Energy self-consumers and renewable energy communities in Italy: New actors of the electric power systems. Renew. Sustain. Energy Rev. 2021, 151, 111565. [CrossRef]

49. Mutani, G.; Beltramino, S.; Forte, A. A clean energy atlas for energy communities in piedmont region (Italy). Int. J. Des. Nat. Ecodyn. 2020, 15, 343-353. [CrossRef]

50. Segrate Municipality. Piano di Governo del Territorio (Municipality Urban Plan). Available online: https://www.comune.segrate. mi.it/servizi/catasto-e-urbanistica/piano-di-governo-del-territorio/ (accessed on 18 December 2021).

51. Istituto Nazionale di Statistica ISTAT. Available online: https:/ / www.istat.it/ (accessed on 18 December 2021).

52. Geoportale of Lombardy Region. Home-Geoportale della Lombardia. Available online: https://www.geoportale.regione. lombardia.it/ (accessed on 15 December 2021).

53. ARERA-Composizione Percentuale del Prezzo Dell'energia Elettrica per un Consumatore Domestico Tipo. Available online: https://www.arera.it/it/dati/ees5.htm (accessed on 2 February 2022).

54. ARERA-Andamento del Prezzo Dell'energia Elettrica per il Consumatore Domestico Tipo in Maggior Tutela. Available online: https:/ / www.arera.it/it/dati/eep35.htm (accessed on 2 February 2022).

55. Istituto Nazionale di Statistica, ISTAT. Consumi Energetici delle Famiglie. Available online: http://dati.istat.it/Index.aspx? DataSetCode=DCCV_CENERG (accessed on 2 February 2022).

56. Ministerial Decree 1444/68. Available online: https://www.gazzettaufficiale.it/eli/id/1968/04/16/1288Q004/sg (accessed on 2 February 2022).

57. Agenzia Nazionale per le Nuove Tecnologie (ENEA). Benchmark di Consumo Energetico Degli Edifici per Uffici in Italia Available online: https:/ / www.enea.it/it/Stampa/File/Rapporto_BenchmarkConsumiUffici_EneaAssoimmobiliare_2019.pdf (accessed on 15 December 2021).

58. European Commission. Photovoltaic Geographical Information System (PVGIS). Available online: https://ec.europa.eu/jrc/en/ pvgis (accessed on 15 December 2021).

59. International Renewable Energy Agency (IRENA). Geothermal Energy. Available online: https://www.irena.org/geothermal (accessed on 22 December 2021).

60. Creamer, E.; Eadson, W.; van Veelen, B.; Pinker, A.; Tingey, M.; Braunholtz-Speight, T.; Markantoni, M.; Foden, M.; Lacey-Barnacle, M. Community energy: Entanglements of community, state, and private sector. Geogr. Compass 2018, 12, e12378. [CrossRef]

61. Moroni, S.; Antoniucci, V.; Bisello, A. Energy sprawl, land taking and distributed generation: Towards a multi-layered density. Energy Policy 2016, 98, 266-273. [CrossRef]

62. Soeiro, S.; Ferreira Dias, M. Renewable energy community and the European energy market: Main motivations. Heliyon 2020, 6, e04511. [CrossRef]

63. Biresselioglu, M.E.; Limoncuoglu, S.A.; Demir, M.H.; Reichl, J.; Burgstaller, K.; Sciullo, A.; Ferrero, E. Legal provisions and market conditions for energy communities in Austria, Germany, Greece, Italy, Spain, and Turkey: A comparative assessment. Sustainability 2021, 13, 11212. [CrossRef] 
64. Brummer, V. Community energy-Benefits and barriers: A comparative literature review of Community Energy in the UK, Germany and the USA, the benefits it provides for society and the barriers it faces. Renew. Sustain. Energy Rev. 2018, 94, 187-196. [CrossRef]

65. Byrnes, L.; Brown, C.; Foster, J.; Wagner, L.D. Australian renewable energy policy: Barriers and challenges. Renew. Energy 2013, 60, 711-721. [CrossRef]

66. Ableitner, L.; Tiefenbeck, V.; Meeuw, A.; Wörner, A.; Fleisch, E.; Wortmann, F. User behavior in a real-world peer-to-peer electricity market. Appl. Energy 2020, 270, 115061. [CrossRef]

67. Ruggiero, S. CO2MMUNITY-Co-Producing and Co-Financing Renewable Community Energy Projects [Working Paper]. 2019. Available online: http:/ / co2mmunity.eu/wp-content/uploads/2019/03/Co2mmunity-working-paper-2.3.pdf (accessed on 28 December 2021).

68. Radtke, J. A closer look inside collaborative action: Civic engagement and participation in community energy initiatives. People Place Policy Online 2014, 8, 235-248. [CrossRef]

69. Hoffman, S.M.; High-Pippert, A. From private lives to collective action: Recruitment and participation incentives for a community energy program. Energy Policy 2010, 38, 7567-7574. [CrossRef]

70. Koirala, B.P.; Araghi, Y.; Kroesen, M.; Ghorbani, A.; Hakvoort, R.A.; Herder, P.M. Trust, awareness, and independence: Insights from a socio-psychological factor analysis of citizen knowledge and participation in community energy systems. Energy Res. Soc. Sci. 2018, 38, 33-40. [CrossRef]

71. Walker, G.; Devine-Wright, P. Community renewable energy: What should it mean? Energy Policy 2008, 36, 497-500. [CrossRef]

72. Rogers, J.C.; Simmons, E.A.; Convery, I.; Weatherall, A. Public perceptions of opportunities for community-based renewable energy projects. Energy Policy 2008, 36, 4217-4226. [CrossRef]

73. Grignani, A.; Gozzellino, M.; Sciullo, A.; Padovan, D. Community cooperative: A new legal form for enhancing social capital for the development of renewable energy communities in Italy. Energies 2021, 14, 7029. [CrossRef]

74. Article 30, Par. 1, of Law Decree 31 May 2021, n. 77-Decreto Semplificazioni Bis. Available online: https://www.gazzettaufficiale. it/eli/id/2021/05/31/21G00087/sg (accessed on 4 February 2022).

75. Decree of the President of the Republic of 6 June 2001, No. 380-Testo Unico in materia Edilizia e Urbanistica. Available online: https:/ / www.parlamento.it/parlam/leggi/deleghe/01378dla.htm (accessed on 1 February 2022).

76. Legislative Decree of 22 January 2004, No. 42-Codice dei Beni Culturali e del Paesaggio. Available online: https://web.camera.it/ parlam/leggi/deleghe/04042dl.htm (accessed on 1 February 2022).

77. Legambiente. Scacco Matto Alle Rinnovabili: Tutta la Burocrazia che Bloccalo Sviluppo delle Rinnovabili Favorendo Gas e Finte Soluzioni; 2021; pp. 20-24. Available online: https://www.legambiente.it/wp-content/uploads/2021/11/Scacco-matto-alle-rinnovabili_ report-2022.pdf (accessed on 1 February 2022).

78. Santoro, E. L'autorizzazione alla realizzazione di impianti di energia eolica tra tutela ambientale e tutela paesaggistica. In Rivista Giuridica dell'ambiente; 2007; n.2., Giuffrè, 369; Available online: http:/ / www.iusimpresa.com/reperibilita.php?id_rivista=196 (accessed on 2 February 2022).

79. Lombardy Regional Law 12/2005 Urban and Territorial Government and Planning. Available online: https://normelombardia. consiglio.regione.lombardia.it/NormeLombardia / Accessibile/main.aspx?view=showdoc\&iddoc=lr002005031100012\%20) (accessed on 28 December 2021).

80. National Legislative Decree D.Lgs. 18 August 2000 n. 267 Testo Unico delle Leggi Sull'ordinamento Degli Enti Locali. Available online: https://web.camera.it/parlam/leggi/deleghe/testi/00267dl.htm (accessed on 28 December 2021). 